\title{
Epidemiology of streptococcal infection with reference to Rheumatic fever
}

\author{
Une $\mathbf{L}^{1}$, Patel $\mathbf{U}^{2}$, Patel NP ${ }^{3}$, Borgaonkar $\mathbf{R V}^{4}$ \\ ${ }^{1}$ Dr Lalit Une*, Professor in Pediatrics, ${ }^{2}$ Dr Umesh Patel*, Associate Professor in Pediatrics, ${ }^{3}$ Dr Narmada P Patel*, Assistant \\ Professor in Medicine, all from L N Medical College, Bhopal*, India. ${ }^{4}$ Dr R V Borgaonkar ${ }^{\infty}$, Professor in Pediatrics, \\ Government Medical College, Aurangabad ${ }^{\infty}$, India
}

Address for correspondence: Dr Lalit Une, Email: lalit_68@yahoo.com

\begin{abstract}
Introduction: Group A hemolytic streptococcal infections have a worldwide distribution among children and it poses an important health problem globally. Group A streptococcal (GAS) serology is used for the diagnosis of post-streptococcal diseases, such as acute rheumatic fever, post-streptococcal Glomerulonephritis and occasionally for the diagnosis of streptococcal pharyngitis. Upper normal limits for streptococcal serology should be determined for individual populations because of differences in the epidemiology of GAS between populations. Material \& Methods: Study materials were divided in 3 groups. Group-A (normal children population), group- B (children clinically diagnosed as acute bacterial sore throat) and group-C (children clinically diagnosed rheumatic fever). ASO titer \& throat culture were assessed in all three groups. Result: When cut off range of ASO titer is $>200 \mathrm{IU} / \mathrm{ml}$, it is positive in $20 \%, 38 \%$ and $54.4 \%$ in Group A, B and C respectively. But When titer range increased to $>400 \mathrm{IU} / \mathrm{ml}$, it was positive in $40 \%, 36.84 \%$ and $44.44 \%$ cases from Group A, B \& C respectively. Conclusion: Cut off point of $200 \mathrm{IU} / \mathrm{ml}$ has limitations in our setup. Use of western cut off $200 \mathrm{IU} / \mathrm{ml}$ needs to be revised in relation to local epidemiology to get less false positive results.
\end{abstract}

Key words: ASO, GAS, Sore throat, Streptococcal sore throat

\section{Introduction}

Streptococcal antibodies tests are used for the diagnosis of antecedent infections caused by the group A streptococcus (GAS) and are particularly useful for the diagnosis of acute rheumatic fever and acute post-streptococcal glomerulonephritis. Acute rheumatic fever is an autoimmune disease that follows infection with GAS; however, the isolation of GAS is uncommon $(<15 \%)$, and so confirmation of the diagnosis often relies on streptococcal antibody tests ${ }^{1}$. While a number of tests utilize different antigens of GAS, the most frequently, performed tests are those that determine the anti streptomycin O (ASO) titer and the anti-DNase B (ADB) titer $^{2,3}$. ASO titer is the commonest test used to detect evidence of streptococcal infection. Ideally, it is recommended that the titer be determined in the acute phase and then determined in the convalescent phase 2-4 weeks later, with a positive result defined as a rise in titer of two fold or more ${ }^{4,5}$. An increase in ASO is almost specific proof of streptococcal infection. The ASO test

Manuscript received: $06^{\text {th }}$ July 2013

Reviewed: $13^{\text {th }}$ July 2013

Author Corrected: $19^{\text {th }}$ Aug 2013

Accepted for Publication: $20^{\text {th }}$ Aug 2013 reaches its peak 3 to 6 weeks following infection, whereas anti DNase reaches its peak slightly later 6 to 8 weeks. However, it is not always practicable to obtain a second sample for titer determination, particularly in developing countries, where acute rheumatic fever is the most common. Therefore, it is generally accepted that if only a single specimen is available, a titer greater than the upper limit of normal at the initial testing can be considered presumptive evidence of a preceding streptococcal infection ${ }^{6}$. Higher the titer more is the possibility of rheumatic fever.

Increased ASO titers support but do not prove the diagnosis of rheumatic fever. Falsely high titers of ASO may be seen in conditions associated with hyperlipedemias such as hepatic, biliary obstruction and nephrosis and myeloma due to monoclonal immunoglobulins ${ }^{7}$.

In developing countries, the high incidence of acute respiratory tract infection assumes special significance due to development of rheumatic fever. The incidence of rheumatic fever may be as high as 3\% during epidemic or as less as $0.3 \%$ during endemic areas ${ }^{1}$. 
In the western setup, an ASO of more than $200 \mathrm{IU} / \mathrm{ml}$ by latex test is considered a screening point (this is equivalent to 333 Todd units by tube test $)^{8}$.

Streptococcal titers vary according to a number of factors, including age and socioeconomic status of population. ASO titer needs to be considered in context of an existing epidemiological pattern. In developed countries, where impetigo caused by GAS is uncommon, streptococcal titers in the population primarily reflect the incidence of pharyngeal infection with GAS; therefore, the titers in healthy people are low in early childhood, rise to a peak in children aged 5 to 15 years, decrease in late adolescence and early adulthood, and then flatten off after that ${ }^{6,8,9}$.

In contrast, in populations with high rates of impetigo, background anti-streptococcal titers are often very high, especially in children, probably because most children tested have had a recent streptococcal infection ${ }^{10,11}$.

Since ASO persists for 4 to 6 months, it is likely that healthy individuals in endemic area may have persistently high titer due to repeated exposure. It is thus necessary to collect data in our own population for any meaningful interpretation.

Because of these differences in titers with age, it is recommended that age-stratified upper-limit-of-normal values be determined for populations of interest by testing people who have not had a recent streptococcal infection ${ }^{6}$.

Age-stratified upper-limit-of-normal reference values have been defined for the U.S. pediatric population, the Australian pediatric population, and the Indian pediatric population and others $(12,13,14,15,16)$

Western studies have demonstrated lack of ASO antibody below 3 years of age. Bhave et al 1991 demonstrated lack of antibody below one year of age. however, unlike western studies $7.9 \%$ of children below 1-3 years of age demonstrated significant ASO antibodies, this difference in epidemiological pattern is well reflected in a different clinical profile, younger children in our country get rheumatic heart disease ${ }^{17}$.

Many ICMR studies show that $5.15 \%$ of healthy school children and $50 \%$ of general population has positive throat culture. Another ICMR study showed that $15 \%$ children had positive throat culture of which $2 / 3$ showed AS0 antibodies. A study from Vellore documented that $39 \%$ of streptococcal pharyngitis has raised antibodies without positive culture.

It is evident from these data that western cut off point 200 $\mathrm{IU} / \mathrm{ml}$ has limitation in our setup. Normal individuals can be misdiagnosed as having recent streptococcal infection while $20 \%$ cases of rheumatic carditis can be missed. This can be overcome by use of paired sera and demonstration of more specific streptococcal antibodies by better tests. There is need to monitor local epidemiology for meaningful interpretation of ASO titer. Use of western cut of point of $200 \mathrm{IU} / \mathrm{ml}$ need to be revised in relation to our local epidemiology.

\section{Material and Methods}

Settings- Tertiary care teaching hospital.

Ethical approval- has been taken from college ethical committee.

The present study comprised of three groups

A) Normal children

B) Children clinically diagnosed as acute bacterial sore throat

C) Children clinically diagnosed as rheumatic fever

\section{Inclusion Criteria's-}

\section{Group A}

1) Children from general population, between 1 month and 15 years of age, attending OPD with no historical or clinical evidence of any infection.

2) Children from local school.

\section{Group B}

1) Children between 1 months and 15 years of age.

2) Children were selected from both upper and lower socioeconomic groups

3) Clinically diagnosed bacterial throat infection.

4) If history of antibiotic therapy prior to presentation, cases were excluded.

5) Children with skin infection were also excluded.

\section{Group C}

1) Patients clinically diagnosed as acute rheumatic fever (carditis, arthritis).

2) Diagnosis of rheumatic fever was done on basis of Jones criteria, revised with addition of WHO recommendation.

Clinical diagnosis of streptococcal sore throat: It was based on 1965 committee report on the prevention of rheumatic fever of the American Heart Association. 


\begin{tabular}{|l|l|}
\hline \multicolumn{1}{|c|}{ Symptoms } & \multicolumn{1}{c|}{ Signs } \\
\hline $\begin{array}{l}\text { 1.Sore throat-sudden onset } \\
\text { \& pain on swallowing }\end{array}$ & 1.Red throat \\
\hline 2.Headache & 2.Exudate \\
\hline 3.Fever & $\begin{array}{l}\text { 3.Lymphadenopathy- } \\
\text { swollen tender lymph } \\
\text { nodes at angle of jaw }\end{array}$ \\
\hline 4.Abdominal Pain & 4.Scarlatiniform rash \\
\hline 5.Nausea \& Vomiting & 5.Acute otitis media \\
\hline & 6.Acute sinusitis \\
\hline
\end{tabular}

In every case of acute rheumatic fever (active carditis, arthritis), detailed history was recorded and a thorough clinical examination was carried out.

\section{Estimation of ASO titer}

ASO titer was estimated by using latex ASL reagent-Rapi text kit manufactured by Hoechst laboratories. The test was carried out by diluting one part of serum to 5 parts of $0.9 \%$ normal saline and then adding one drop reagent to one drop of diluted serum. Presence of marked agglutination seen after two minutes indicated positive test. Positive agglutination with 1:5 dilution indicated ASO antibodies of $200 \mathrm{IU} / \mathrm{ml}$, while with 1:10 dilution indicate $400 \mathrm{IU} / \mathrm{ml}$ and so on.

\section{Throat culture}

Taking all standard precautions throat cultures were taken with acotton tipped applicator, swabbed against both tonsillar areas. Throat swab were immediately cultured on blood agar plate. The colonies of beta-hemolytic streptococci on blood agar plates were surrounded by a clear zone in which few or no intact erythrocytes were visible.

\section{Results}

The present study was carried out on 182 cases of rheumatic fever, 50 cases of acute bacterial sore throat and 100 cases of normal child.

Table No: 01 Age Distribution

\begin{tabular}{|c|c|c|c|c|c|c|}
\hline \multirow[t]{2}{*}{ Age in years } & \multicolumn{2}{|c|}{ Group A } & \multicolumn{2}{|c|}{ Group B } & \multicolumn{2}{|c|}{ Group C } \\
\hline & No of cases & Percentage & No of cases & Percentage & No of cases & Percentage \\
\hline $0-1$ & 05 & 05 & 01 & 02 & 00 & 00 \\
\hline $1+$ & 06 & 06 & 01 & 02 & 00 & 00 \\
\hline $2+$ & 04 & 04 & 05 & 10 & 00 & 00 \\
\hline $3+$ & 09 & 09 & 03 & 06 & 00 & 00 \\
\hline $4+$ & 05 & 05 & 07 & 17 & 01 & 00.54 \\
\hline $5+$ & 04 & 04 & 04 & 08 & 06 & 03.29 \\
\hline $6+$ & 11 & 11 & 05 & 10 & 10 & 05.49 \\
\hline $7+$ & 08 & 08 & 10 & 20 & 08 & 04.39 \\
\hline $8+$ & 12 & 12 & 06 & 12 & 45 & 24.72 \\
\hline $9+$ & 07 & 07 & 03 & 06 & 22 & 12.08 \\
\hline $10+$ & 10 & 10 & 02 & 04 & 26 & 14.28 \\
\hline $11+$ & 05 & 05 & 00 & 00 & 17 & 09.34 \\
\hline $12+$ & 07 & 07 & 01 & 02 & 21 & 11.53 \\
\hline $13+$ & 03 & 03 & 01 & 02 & 11 & 06.04 \\
\hline $14+$ & 04 & 04 & 01 & 02 & 15 & 08.24 \\
\hline Total & 100 & 100 & 50 & 100 & 182 & 100 \\
\hline
\end{tabular}


Table No-01 shows that there was no case up to 4 years in Group-C. Maximum cases occurred in 8-10 years of age (51.05\%). Mean age of patients in Group A, B \& C were 7.6 years, 7.75 years \& 9.75 years.

Table No 02: Distribution of cases according to the presenting symptoms in children with acute bacterial throat infection

\begin{tabular}{|c|c|c|}
\hline Presenting Symptoms & No of cases & Percentage \\
\hline 1.Sore throat of sudden onset \& Pain on swallowing & 42 & 70 \\
\hline 2.Fever & 35 & 30 \\
\hline 3.Headache & 15 & 10 \\
\hline 4.Abdominal pain & 05 & 16 \\
\hline
\end{tabular}

From table No-02, it is clear that sore throat of sudden onset \& pain on swallowing was the most common symptom and present in $84 \%$ cases.

Table No 03: Distribution of cases according to presenting sign in children with acute bacterial sore throat

\begin{tabular}{|c|c|c|}
\hline Presenting sign & No of cases & Percentage \\
\hline Red throat & 38 & 58 \\
\hline Exudate & 29 & 52 \\
\hline Lymphadenopathy & 26 & 04 \\
\hline Rash & 02 & 04 \\
\hline Acute otitis media & 02 & 04 \\
\hline
\end{tabular}

From table No-03 it is clear that red throat is the most common presenting sign ( $76 \%$ cases) in acute bacterial sore throat.

Table No 4: Distribution of ASO titer in different groups

\begin{tabular}{|c|c|c|c|c|c|c|c|c|c|}
\hline \multirow{2}{*}{$\begin{array}{c}\text { Age in } \\
\text { years }\end{array}$} & \multicolumn{3}{|c|}{ Group-A } & \multicolumn{3}{|c|}{ Group-B } & \multicolumn{3}{|c|}{ Group-C } \\
\hline & $\begin{array}{l}\text { No of } \\
\text { cases }\end{array}$ & $\begin{array}{c}\text { ASO } \\
\text { positive }\end{array}$ & $\%$ & $\begin{array}{l}\text { No of } \\
\text { cases }\end{array}$ & $\begin{array}{c}\text { ASO } \\
\text { positive }\end{array}$ & $\%$ & $\begin{array}{l}\text { No of } \\
\text { cases }\end{array}$ & $\begin{array}{c}\text { ASO } \\
\text { positive }\end{array}$ & $\%$ \\
\hline $0-1$ & 05 & 00 & 00 & 01 & 00 & 00 & 00 & 00 & 00 \\
\hline $1+$ & 06 & 00 & 00 & 01 & 00 & 00 & 00 & 00 & 00 \\
\hline $2+$ & 04 & 00 & 00 & 05 & 02 & 40.00 & 00 & 00 & 00 \\
\hline $3+$ & 09 & 01 & 11.11 & 03 & 01 & 33.33 & 00 & 00 & 00 \\
\hline $4+$ & 05 & 00 & 00 & 07 & 02 & 28.57 & 01 & 00 & 00 \\
\hline $5+$ & 04 & 02 & 50.00 & 04 & 02 & 50.00 & 06 & 03 & 50.00 \\
\hline $6+$ & 11 & 05 & $45 / 45$ & 05 & 01 & 20.00 & 10 & 06 & 60.00 \\
\hline $7+$ & 08 & 01 & 12.50 & 10 & 06 & 60.00 & 08 & 06 & 75.00 \\
\hline $8+$ & 12 & 01 & 08.33 & 06 & 02 & 33.33 & 45 & 28 & 62.23 \\
\hline $9+$ & 07 & 02 & 28.57 & 03 & 01 & 33.33 & 22 & 11 & 50.00 \\
\hline $10+$ & 10 & 01 & 10.00 & 02 & 00 & 00 & 26 & 16 & 61.54 \\
\hline $11+$ & 05 & 01 & 20.00 & 00 & 00 & 00 & 17 & 07 & 41.17 \\
\hline $12+$ & 07 & 03 & 42.85 & 01 & 01 & 100 & 21 & 13 & 61.90 \\
\hline $13+$ & 03 & 02 & 66.66 & 01 & 00 & 00 & 11 & 04 & 36.36 \\
\hline $14+$ & 04 & 01 & 25.00 & 01 & 01 & 100 & 15 & 05 & 20.00 \\
\hline $\begin{array}{c}\text { Total } \\
(\%)\end{array}$ & 100 & $\begin{array}{c}20 \\
(20 \%)\end{array}$ & & 50 & $\begin{array}{c}19 \\
(38 \%)\end{array}$ & & 182 & $\begin{array}{c}99 \\
(54.4 \%)\end{array}$ & \\
\hline
\end{tabular}


Table No-04 shows that ASO titer is also positive in 20\% normal population and nearly $38 \%$ in children suffering from sore throat. Another important observation from this table that $54.5 \%$ already diagnosed cases of rheumatic fever, also have positive ASO titer.

Table No 05: Distribution of ASO positive result

\begin{tabular}{|c|c|c|c|}
\hline \multirow[t]{2}{*}{ Group } & \multirow{2}{*}{$\begin{array}{c}\text { No of positive } \\
\text { Cases }\end{array}$} & \multicolumn{2}{|c|}{ ASO Titer (IU/ml) } \\
\hline & & $>200$ to $<400$ & $>400$ \\
\hline Group-A & 20 & 12 & 08 \\
\hline Group-B & 19 & 12 & 07 \\
\hline Group-C & 99 & 58 & 41 \\
\hline
\end{tabular}

Table No-05 shows that in Group A 20\% cases have ASO titer positive despite no signs \& symptoms of acute rheumatic fever and out of them 08 (40\%) having ASO titer $>400 \mathrm{IU} / \mathrm{ml}$. Percentage of ASO titer is higher in patients with acute sore throat \& patient already diagnosed rheumatic fever.

Table No 06: Throat Culture and ASO in Acute Pharyngitis

\begin{tabular}{|c|c|c|c|}
\hline Throat Culture & ASO Titer & Number & Percentage \\
\hline Positive & Positive & 13 & $26.00 \%$ \\
\hline Positive & Negative & 03 & $06.00 \%$ \\
\hline Negative & Positive & 06 & $12.00 \%$ \\
\hline Negative & Negative & 50 & $100 \%$ \\
\hline
\end{tabular}

Table No 06 shows that there is $32 \%$ (16 cases) patient had positive throat culture for Group-A beta hemolytic streptococci and $38 \%$ (19 cases) positive for ASO titer. Both culture and ASO titer positive were seen in $26 \%$ (13 cases) patients.

\section{Discussion}

The present study is aimed to determine ASO antibodies in normal children, as compared to patient of rheumatic fever and clinically diagnosed streptococcal sore throat and corelated with bacteriological culture of throat.

Except few, most of studies done previously are not comparable with present study as distribution of cases according to age group is not available. Siegel et al ${ }^{(19)}$ studied 245 children with streptococcal pharyngitis with age group 3-16 years, Goslings et al studied 206 patients of pharyngitis, but exclude patients with age less than 4 years, Valkenburg et al ${ }^{(18)}$ include 229 patient in their study with age limit between 4 years to 100 years. Grace Koshi et $\mathrm{al}^{(20,21)}$ studied 248 children with streptococcal pharyngitis with age group 45 days to 15 years.
In this study maximum number of patients (40.72\%) occurred in 3-5 years, as compared to our study where maximum number of cases $(52 \%)$ found in 6-10 years of age.

Bhave et al $^{17}$ studied (1991) 787 normal children for estimation of ASO titer. In the study, a large number of normal children showed positive ASO antibodies, progressively increased from $7.9 \%$ in age group 1-3 years to $15.8 \%$ in age group of $9-12$ years. Similar type of observations was also found in our study but showed higher percentage of positive cases than Bhave et al. This observation showed that a large number of children have ASO antibodies without obvious evidence of recent 
Research Article

streptococcal infection. This may be due to frequent subclinical infection in our country.

\begin{tabular}{|c|c|c|c|c|c|c|}
\hline $\begin{array}{c}\text { Age } \\
\text { (in } \\
\text { year } \\
\text { s) }\end{array}$ & \multicolumn{3}{|c|}{ Bhave et al } & \multicolumn{3}{c|}{ Present Study } \\
\cline { 2 - 7 } & $\begin{array}{c}\text { No } \\
\text { Cas } \\
\text { es }\end{array}$ & $\begin{array}{c}\text { ASO } \\
\text { Positi } \\
\text { ve }\end{array}$ & $\begin{array}{c}\text { Positi } \\
\text { ve }\end{array}$ & $\begin{array}{c}\text { No } \\
\text { of } \\
\text { cas } \\
\text { es }\end{array}$ & $\begin{array}{c}\text { ASO } \\
\text { Positi } \\
\text { ve }\end{array}$ & $\begin{array}{c}\text { Positi } \\
\text { ve }\end{array}$ \\
\% \\
\hline$<1$ & 67 & 00 & 00 & 05 & 00 & 00 \\
\hline $1-3$ & 114 & 09 & 07.90 & 19 & 01 & 05.26 \\
\hline $4-8$ & 153 & 18 & 11.80 & 40 & 09 & 22.50 \\
\hline $9-12$ & 165 & 26 & 15.80 & 29 & 07 & 24.13 \\
\hline$>12$ & 288 & 31 & 10.80 & 07 & 07 & 43.84 \\
\hline Tota & 787 & 84 & & 100 & 20 & \\
1 & & & & & & \\
\hline
\end{tabular}

Western studies have demonstrated absence of ASO antibodies below 3 years of age ${ }^{1}$. Our study demonstrates $5.26 \%$ of positive ASO antibodies. This could be because of frequent subclinical infection.

\begin{tabular}{|c|c|c|c|c|}
\hline \multirow{2}{*}{$\begin{array}{l}\text { Name of } \\
\text { study }\end{array}$} & \multirow{2}{*}{$\begin{array}{l}\text { No of } \\
\text { cases }\end{array}$} & \multirow{2}{*}{$\begin{array}{c}\text { No of } \\
\text { ASO } \\
\text { positive } \\
\text { cases }\end{array}$} & \multicolumn{2}{|c|}{ ASO titer (IU/ml) } \\
\hline & & & $\begin{array}{c}>200- \\
<400\end{array}$ & $>400$ \\
\hline $\begin{array}{c}\text { Bhave et } \\
\text { al }\end{array}$ & 787 & 84 & $\begin{array}{c}84 \\
(10.7 \%)\end{array}$ & $\begin{array}{c}17 \\
(2.1 \%)\end{array}$ \\
\hline $\begin{array}{c}\text { Present } \\
\text { study }\end{array}$ & 100 & 20 & $20(20 \%)$ & $\begin{array}{c}08 \\
(8.0 \%)\end{array}$ \\
\hline
\end{tabular}

Bhave et a ${ }^{17}$ showed that $84(10.7 \%)$ had ASO titer $>200$

$\mathrm{IU} / \mathrm{ml}$ and out of them $17(2.1 \%)$ had ASO titer $>400$

IU/ml. In present study $20(20 \%)$ children had ASO titer $>200 \mathrm{IU} / \mathrm{ml}$ and $8(8 \%)$ had $>400 \mathrm{IU} / \mathrm{ml}$.

Many studies conducted previously also shown significantly high percentage of positive ASO titer. This is because poor socio-economic status and recurrent subclinical streptococcal infections.

Table showing ASO titer in patients with Acute Rheumatic Fever

\begin{tabular}{|c|c|c|}
\hline Study Name & $\begin{array}{c}\text { Number of } \\
\text { cases }\end{array}$ & $\begin{array}{c}\text { ASO Titer } \\
\text { Positive } \\
(\mathbf{\%})\end{array}$ \\
\hline Stollerman et al (22) & 580 & $78.0 \%$ \\
\hline Saha et al (1980) & 40 & $88.0 \%$ \\
\hline Bhave et al (1991) & 522 & $77.0 \%$ \\
\hline Present study & 182 & $31.8 \%$ \\
\hline
\end{tabular}

Table showing positive throat swab culture for Group A beta hemolytic streptococci in Acute Pharyngitis

\begin{tabular}{|c|c|}
\hline Name of study & $\begin{array}{c}\text { Positive throat culture for } \\
\text { Group A beta hemolytic } \\
\text { streptococci }\end{array}$ \\
\hline Siegel et al (1961) & $86.0 \%$ \\
\hline Grace Koshi et al (1961) & $13.7 \%$ \\
\hline Gosling et al (1963) & $73.0 \%$ \\
\hline Bhave et al (1991) $)^{17}$ & $65.0 \%$ \\
\hline Present study & $32.0 \%$ \\
\hline
\end{tabular}

There are high chances of growth of group A beta Hemolytic streptococci in throat swab culture in case of acute bacterial pharyngitis. Various studies have shown positive culture from 13.7 to $86.0 \%$. Our study showed $32.0 \%$ positive rate. High prevalence of throat culture was because of lower socio-economic status, poor nutrition, over crowing and lack of proper medical care.

\section{Conclusions}

Sore throat \& pain on swallowing was the commonest symptoms and red throat was the commonest sign. Diagnosis of acute rheumatic fever was done clinically based on the revised Jone's criteria with addition of WHO recommendations.

It is evident from our data that the western cut off point of $200 \mathrm{IU} / \mathrm{ml}$ has limitations in our setup. Some of normal individual can be misdiagnosed as recent streptococcal infection while some cases of rheumatic carditis can be missed. This can be overcome by use of paired sera \& demonstration of more specific streptococcal antibodies by better tests. 
Over diagnosis of rheumatic fever is a distinct possibility, if diagnosis is based on a single ASO estimation, especially in presence of vague clinical parameters. When in doubt, a repeat ASO titer \& additional tests for more specific antibodies should be performed. Use of western cut off 200 $\mathrm{IU} / \mathrm{ml}$ needs to be revised in relation to local epidemiology.

Funding: Nil

\section{Conflict of interest: Nil}

\section{Permission from IRB: Yes}

\section{References}

1. Martin DR, Voss LM, Walker SJ, Lennon D. Acute rheumatic fever in Auckland, New Zealand: spectrum of associated group A streptococci different from expected. Pediatr Infect Dis J. 1994; 13 (4): 264-269.

2. Kaplan EL, Ferrieri P, Wannamaker LW. Comparison of the antibody response to streptococcal cellular and extracellular antigens in acute pharyngitis. J Pediatr.1974; 84(1):21-28.

3. Shet A, Kaplan EL. Clinical use and interpretation of group A streptococcal antibody tests: a practical approach for the pediatrician or primary care physician. Pediatr Infect Dis J.2002; 21(5):420-426.

4.Wannamaker LW, Ayoub EM. Antibody titers in acute rheumatic fever. Circulation. 1960; 21(Apr):598-614.

5. Machado CS, Ortiz K, Martins Ade L, Martins RS, Machado NC. Antistreptolysin O titer profile in acute rheumatic fever diagnosis. J Pediatr (Rio J). 2001; $77(2): 105-111$.

6. Klein GC, Baker CN, Jones WL. "Upper limits of normal" antistreptolysin $\mathrm{O}$ and antideoxyribonuclease B titers. Appl Microbiol. 1971; 21(6): 999-1001.

7. Giovanna Zaninetta M, Moccia F, Paolo Mazzarello G, Mansuino P, Morra L. Evaluation of antibody specificity of the monoclonal component in a case of Waldenström's macroglobulinemia. 1992;7(1):42-45.

8. Sethi S, Kaushik K, Mohandas K, Sengupta C, Singh S, Sharma M. Anti-streptolysin O titers in normal healthy children of 5-15 years. Indian Pediatr. 2003;40(11):10681071.

9. Kaplan EL, Rothermel CD, Johnson DR. Antistreptolysin $\mathrm{O}$ and anti-deoxyribonuclease B titers: normal values for children ages 2 to 12 in the United States. Pediatrics. 1998; 101(1):86-88

10. Nimmo GR, Tinniswood RD, Nuttall N, Baker GM, McDonald B. Group A streptococcal infection in an aboriginal community. Med. J. 1992; 157(8):521-522.

11. VanBuynder PG, Gaggin JA, Martin D, Pugsley D, Mathews JD. Streptococcal infection and renal disease markers in Australian aboriginal children. Med. J. Aust.1992; 156(8):537-540.

12. Blyth CC, Robertson PW. Anti-streptococcal antibodies in the diagnosis of acute and poststreptococcal disease: streptokinase versus streptolysin $\mathrm{O}$ and deoxyribonuclease B. Pathology. 2006; 38(2):152-156.

13. Danchin MH, Carlin JB, Devenish W, Nolan TM, Carapetis JR. New normal ranges of antistreptolysin $\mathrm{O}$ and anti-deoxyribonuclease B titres for Australian children. J. Paediatr Child Health. 2005; 41(11):583-586.

14. Kaplan EL, Rothermel CD, Johnson DR. Antistreptolysin $\mathrm{O}$ and anti-deoxyribonuclease B titers: normal values for children ages 2 to 12 in the United States. Pediatrics. 1998; 101 (1 pt1): 86-88

15. Karmarkar M G, Venugopal V, Joshi L, Kamboj R. Evaluation \& revaluation of upper limits of normal values of anti-streptolysin $\mathrm{O}$ and ant-deoxyribonuclease $\mathrm{B}$ in Mumbai. Indian J. Med. Res. 2004:119(Suppl.) 26-28.

16. Royston, P. Constructing time-specific reference ranges. Stat. Med. 1991; 10(5):675-690.

17. Bhave SY, Kinikar A, Sane S, Agarwal M, Amdekar YK. Epidemiology of streptococcal infection with reference to rheumatic fever. Indian Pediatr. 1991; 28(12):1503-1508.

18. Goslings WRO, Valkenburg HA, Bots AW, Lorrier JC. Attack Rates of Streptococcal Pharyngitis, Rheumatic Fever and Glomerulonephritis in the General Population A Controlled Pilot Study of Streptococcal Pharyngitis in One Village. N Engl J Med. 1963; 268(13):687-694. 
19.Siegel AC, Johnson EE, Stollerman GH. Controlled Studies of Streptococcal Pharyngitis in a Pediatric Population - Factors Related to the Attack Rate of Rheumatic Fever. N Engl J Med. 1961; 265(12):559-566.

20. Koshi G, Benjamin V.Surveillance of streptococcal infections in children in a south Indian community-a pilot survey. Indian J Med Res.1977; 66(3):379-88.
21. Koshi G, Jadhav M, Myers RM. Streptococcal pharyngitis in children. Indian J Med Res.1970; 58(2):161171.

22. Stollerman GH, Lewis AJ, Schultzi I, Taranta A. Relationship of immune response to group A streptococci to the course of acute, chronic and recurrent rheumatic fever. Am J Med.1956; 20(2):163-169.

\section{How to cite this article?}

Une L, Patel U, Patel NP, Borgaonkar RV. Epidemiology of streptococcal infection with reference to Rheumatic fever. Int $J$ Med Res Rev 2013;1(3):106-113. doi: 10.17511/ijmrr.2013.i03.05 